\title{
Learning From Failure
}

In this issue, JAB continues a series of editorials from highly impactful faculty and researchers on "lessons learned" throughout their careers or lives. The hope is that the rest of us can benefit from their experiences. I would like to thank these individuals for sharing their thoughts with us.

—Michael Madigan, Editor-in-Chief

James A. Ashton-Miller (jaam@umich.edu) is a professor of Mechanical Engineering and the director of the Biomechanics Research Laboratory at the University of Michigan. Ronald F. Zernicke is a professor of Orthopaedic Surgery, Kinesiology, and Biomedical Engineering and the director of the UM Exercise \& Sport Science Initiative at the University of Michigan.

"Honorable errors do not count as failure in science, but as seeds for progress in the quintessential activity of correction." —Stephen Jay Gould

James: We have been asked to write an editorial on any topic. I have been thinking about writing about failure and what it has taught me.

Ron: How about doing a piece together because I've had my share of failures, and failures can be significant stimuli for lessons in life and scientific discovery.

James: OK! How about having a beer to mull things over, and then we could each put some ideas down on paper and see where it goes?

James: My biggest personal failure was being sent down (ie, thrown out of) from a university in England in my second year of engineering. There being no quizzes or mid-terms, everything depended on passing all the finals in May to move on. Too many extracurricular activities led to my failing a final. I was out. But it wasn't that I hadn't learned anything in those activities. I was a collegiate athlete, played in a popular band, helped run a folk music club, and was forever repairing my (death trap) 1939 MG PB roadster to keep it on the road. Playing traditional folk music brought me into a fascinating world quite separate from university life. It was full of wonderfully gifted musicians from the shipyards, coal mines, fishing industry, and Scottish borders of Northern England from whom I learned about the Northumberland pipes, plenty of good music, and much about life. But failing that exam meant I had to eat humble pie. That meant leaving to go home to get a job and retaking the exam to get back in to complete my degree.

What I learned: It didn't take many days as a worker on a production line drilling air compressor castings before I resolved to never again turn in anything that I wasn't proud of. That remains as true today as it did then - whether for a grant proposal, a paper, or anything else. In fact, it's what drives me to start my National Institutes of Health grant proposals a year ahead of the due date. When venturing into terra incognita, it can take that long to frame the question, refine the hypotheses, and develop the methods and pilot data needed to convince reviewers. To that end, I think of writing as "painting with words." One can do worse than channel the brilliance of Picasso, who used no more pen strokes than were absolutely necessary, or Shakespeare, who used no more words than fit into a 14-line sonnet, to employ words economically in conveying what is needed.

Ron: In fourth grade, I received my first ice skates, and as I excitedly bounded onto the frozen pond, I promptly severely sprained both my ankles. That certainly put a damper on my mobility! Those injuries were the start of a long history of chronic ankle problems, and as I avidly participated in high school and university sports (eg, football, wrestling, and track and field), I would typically tape my ankles and then tape again over my shoes to try to reduce the frequency of ankle sprains.

What I learned: Over the years, I, of course, not only learned to tape my own ankles, but my injuries channeled my curiosity into movement biomechanics, anatomy, and musculoskeletal injuries and their prevention - all which have permeated my academic and research interests for decades. I learned to blend my athletic interests and injuries with my avid interest in biomechanics.

James: In middle school, I was a somewhat precocious 3-sport athlete playing soccer, hockey, and cricket on school teams with boys 3 years older than I was. When spring came around, I was the lead cricket bowler (pitcher): few people, including Prince Charles, seemed able to hit my balls which swerved one way in the air and bounced the other to strike the wicket. I couldn't know it at the time, but cricket fast bowling is now a known risk factor for intervertebral disc herniations. Bruce Elliot has shown that those with counter rotation of the shoulder over 40 degrees and a greater release height are at particularly high risk-in other words, me.

My low back pain started when I was 14 years old and laid me up for a week of agony in bed, most likely with a central disc protrusion because there was no sciatic nerve impingement at that time. A Norwegian surgeon, Henrik Weber, showed that for most people with disc protrusions who need surgery at 42 years of age, their low back pain did not start until the age of $\sim 27$ years. That means the disc, a wonderfully tough laminated structure, can take 15 years to fail and cause a protrusion large enough to trap nearby nerves. In retrospect, I realize that at the age of 14 years, cricket bowling had aged my growing discs by 13 years through an overuse injury. This was caused by lack of systematic training because we didn't know better, and the repeated and forceful trunk lateral bending, axial twisting, and trunk flexion required to bowl a ball on the run at $80 \mathrm{mph}$.

That first-hand experience of a low back failure sparked a lifelong curiosity in the pathomechanics of injury because once we understand the causes better we can prevent them. It probably is the reason why I would later come to write my $\mathrm{PhD}$ dissertation on the spine-on the role of growth in causing progression of adolescent idiopathic scoliosis. It probably also underlies why I would be so fortunate to later be running biomechanical tests of lumbar spine segments with Albert B. Schultz, at the time the leading spine biomechanist, and Gunnar B.J. Andersson, the leading spine orthopedist, who did the pioneering experiments on the effect of posture on intradiscal pressures that underlay the design of the Volvo car seat design and the development of today's lifting guidelines. 
What I learned: Follow your own interests and good things will happen.

Ron: In my first semester as a new assistant professor at UCLA, I co-taught a human neuromuscular anatomy course to more than 400 students. I had just arrived with my new $\mathrm{PhD}$ diploma in-hand from the University of Wisconsin, and I was confident that I "knew my stuff." The lead instructor in the course was Judith L. Smith - an exceptionally gifted teacher, who had received the all-university Distinguished Teaching Award the preceding year. About halfway through the semester, Dr Smith had to go to a scientific conference for a week, and I took over the lectures. I was presenting the intricate details of the anatomy of the upper extremity and hand, and frequently during the lectures, I would ask if there were any questions. All that week, there were no questions. I thought ... they're really getting this; this is great; nothing to this teaching business. The last day of that week, a student in the back row of the large lecture hall raised her hand and asked ". . . isn't Dr. Smith ever coming back?"

What I learned: It was a difficult but highly effective lesson in humility. When Dr Smith returned, I made sure that I absorbed as much as I could from her brilliant teaching style and approach - she would become one of my closest colleagues, research collaborator, and treasured mentors. Be willing to learn, take direction and advice, and value being "uncomfortable"-you must step outside your comfort zone to grow.

James: In the late 1980s, Albert Schultz and I sat down to write a renewal of one of our National Institutes of Health grants on low back pain. Neither of us could muster much enthusiasm because we realized that better imaging was needed to visualize in detail what was wrong. (I believe that still to be the case.) So we had to admit to ourselves that our biomechanical approach was failing to bring the answers that were needed. But at about that time, we learned of problems with as large or even larger socioeconomic consequences than back pain. How? A geriatrician asked for help in studying why the elderly fall, a physiatrist interested me in diabetic falls, a chance meeting over a cadaver with a gynecologist led to my getting interested in women's health and the problem of female pelvic floor injuries due to vaginal birth, and an orthopedist interested me in anterior cruciate ligament (ACL) injuries-initiating 3 lines of research that I continue to work on $\sim 30$ years later.

What I learned: When one no longer burns with passion to find the answer to a research question, don't flog a dead horse. There are plenty of worthwhile, even nontraditional, problems to work on if one is receptive to taking on new challenges and fortunate to have talented colleagues in different disciplines.

Ron: Building on my $\mathrm{PhD}$ research, when I arrived at UCLA, my projects were singularly focused on analyzing human biomechanics using rigid body dynamics. That focus has continued over these decades, but a one-of-a-kind "failure"- an event that led to first biomechanical analysis of a human patellar tendon rupture during actual sports competition ${ }^{1}$ - catalyzed me to develop new research interests in connective tissue and bone adaptation and injury. To put this failure in context, my PhD student (John Garhammer) and I were collecting high-speed cinematographic data for all weight classes at the US Men's National Weightlifting Championships; one of the competitors, who was 29-year-old and world-class caliber, completely ruptured his right patellar tendon during a clean and jerk lift. This lifter had no previous injury to his right knee. Using dynamics equations to model the lifter, we quantified the time course and magnitudes of the hip, knee, and ankle joint moments of force and tensile loading of the patellar tendon in the movements leading up to the rupture and throughout the actual rupture. The ultimate loads in this lifter's patellar tendon, at the time of rupture, were an extraordinary 17.5 times the lifter's body weight.

What I learned: As James did, I too learned to follow my interests, adapt, and embrace new opportunities. As a result of this extraordinary failure, my interest in connective tissue properties (eg, bone, ligament, and tendon) was piqued, and I enthusiastically and systematically developed expertise and research projects in those areas.

James: The current dogma on ACL failure is that it is caused by a single overload of the ACL during a jump landing or cut. But to me that didn't explain why an ACL could suddenly fail in a perfectly routine jump landing or cut an athlete had performed hundreds of times before. Some years ago, it seemed to me that research in the field had stagnated and become incremental. When I mentioned that to a talented orthopedic collaborator, Edward Wojtys, I suggested "Let's start with a clean sheet of paper and figure out why an ACL suddenly fails in a seemingly standard maneuver" the athlete has done many times before. He was interested because he repaired ACL ruptures. I suggested that if the ACL failed suddenly during such a maneuver, as they often did, then the cause could be a material fatigue failure of the ligament due to an accumulation of microdamage that slowly weakens the ligament over multiple loading cycles unless enough time is provided for it to repair. This behavior is observed in many materials, including tendon, and results in sudden unexpected failure, as is the case with many ACL injuries. Importantly, this hypothesis does not rule out an ACL failure due to a single overload; rather, it includes it—as well as explaining those failures in which the ACL fails under submaximal loads.

It has taken us more than 10 years to acquire data demonstrating that in fact ACL fatigue failure is a possibility along with direct evidence of the microdamage involved. In Chen et al, ${ }^{2}$ we demonstrated that one can cause damage to accumulate at the molecular, cellular, and ultrastructural levels at the ACL femoral enthesis of cadavers under repetitive submaximal loading, and we also observed a similar damage signature in the femoral entheses of ACLs removed from living athletes at the time of their surgical repair. Savio Woo showed that the maximal tensile load that a healthy young adult ACL could withstand under 1 loading cycle is about $500 \mathrm{lbf}$. As an example, that healthy young adult ACL can fail under 1 supramaximal loading cycle of $501 \mathrm{lb}$ or, say, 10 submaximal loading cycles of $450 \mathrm{lb}$, or 20 submaximal loads of $400 \mathrm{lb}$, etc., in a 3-month period if not enough time is allowed for the microdamage in the Type I collagen to be repaired. Yet, there is also a threshold, say, $250 \mathrm{lb}$, below which the ACL will not fail under any number of loading cycles.

I view this as a paradigm shift because this repetitive loading failure behavior, known as low-cycle material fatigue, has not been demonstrated in ligaments before. If corroborated by others, its significance is that coaches, trainers, and athletes will know that the ACL has a material fatigue limit in terms of how many highloading cycles it can withstand before failure. This is like the Little League Pitch Count in baseball that is used to protect young pitchers against too much ulnar collateral ligament damage. One cannot change how hard athletes compete in games. But one can change how many loading cycles they do in practice drills. We have found that a single-leg landing or cut with internal tibial rotation particularly stresses the ACL, so coaches can learn to ration the number of more strenuous such moves in practice.

What I learned: Don't be swayed by speakers who seem to have all the answers at their fingertips. Time may prove them 
partially or completely wrong. Trust your instincts, keep things simple, and bounce your ideas off people who you can trust to provide critical feedback.

Ron: When I think of a successful "reversal" of failure, I immediately am reminded of the Hip and Knee Replacement Project that was developed in the Province of Alberta, Canada. ${ }^{3}$ Prior to the development of a new, integrated continuum of care for total hip replacements and total knee replacements, the health care system in Alberta was failing to provide optimal arthroplasty surgeries for its citizens. Most patients had to wait more than 85 weeks for their arthroplasties, and during that extended wait, they frequently experienced decreased quality of life, high pain levels, and, at times, loss of livelihood. To rectify this dire situation, Alberta orthopedic surgeons, led by Dr Cy Frank, mobilized all arthroplasty surgeons in the province and secured provincial and peer-reviewed funding to design and test a province-wide integrated continuum of care, which included contracts for patients to empower them and make each one accountable, aligning and linking of services to be patient-focused, developing case managers to facilitate service delivery for each patient, standardizing the care path based on evidence, and implementing common (electronic) medical information systems.

In collaboration with the provincial orthopedic surgeons, the Alberta Bone and Joint Health Institute, which I had the privilege of serving as executive director, developed and implemented a randomized controlled study of the "standard-of-care path" versus the "integrated care path," with more than 3400 patients enrolled, hundreds of referring physicians involved, and 20 of Alberta's highest-volume joint replacement surgeons participated. When the final results were analyzed for the 2 care paths, patients who went through the new integrated care path had an average wait for surgery of 23 weeks (vs $87 \mathrm{wk}$ ), $85 \%$ of the patients were mobilized the day of surgery (vs 31\%), and 68\% went directly home with family in-home support (vs 56\%). There was no difference in surgical complications between the 2 care paths, and the new way produced reductions in average surgery time, stay in hospital, and hospital cost. The new approach was faster, better, and cheaper-as supported by solid scientific evidence. This new care path is currently being provincially funded and implemented throughout all Alberta. Alberta and the Provincial Bone and Joint Health Institute were recognized by the Canadian Institutes for Health Research with the prestigious CIHR Partnership Award for this unique contribution to reducing wait times and significantly improving the quality of patient care.

What I learned: Failed health care systems can be fixed. Through concerted, collective, and comprehensive planning and implementation, dramatic and significant changes can be made to benefit public health and wellness.

James: I have failed more times than I care to admit and having to learn each time keeps one humble. But I have succeeded in the things I think are important: keeping one's word to family, colleagues, and friends. At my wedding to my wife Kathy I took an oath that I would be true to her no matter what. Today, after almost 50 years, we are still happily married with wonderful children and grandchildren. What could be better than that?

Ron: I enthusiastically echo James' summary statement . . . even to the point that my wife, too, is named Kathy!

James: What was I thinking, we never got that beer!

James A. Ashton-Miller and Ronald F. Zernicke University of Michigan

\section{References}

1. Zernicke RF, Garhammer J, Jobe FW. Human patellar-tendon rupture. J Bone Joint Surg Am. 1977;59(2):179-183.

2. Chen JJ, Kim J, Shawn WH, et al. An anterior cruciate ligament failure mechanism. Am J Sports Med. 2019;47(9):2067-2079. doi:10. $1177 / 0363546519854450$

3. Gooch K, Marshall DA, Faris PD, et al. Comparative effectiveness of alternative clinical pathways for primary hip and knee joint replacement patients: a pragmatic randomized, controlled trial. Osteoarthritis Cartilage. 2012;20(10):1086-1094. 